\title{
Call Me by My Name
}

\author{
Sarah Elliott
}

\section{Response to the ATR Debate Proposition: 'It is important and necessary to make clear distinctions between (irregular) migrants, refugees and trafficked persons.'}

Please cite this article as: S Elliott, 'Call Me by My Name', Anti-Trafficking Review, issue 11, 2018, pp. 133-136, www.antitraffickingreview.org

The image of rubber dinghies densely packed with people floating precariously in the Mediterranean Sea has become a symbol of our times. Among those in peril are persons who may have fled conflict, others who have left poverty and many who have suffered exploitation en route. Upon arrival, states are obliged to meet their immediate needs and to determine for what reasons they came, thereby identifying their rights under international and domestic law.

It has been argued that categorical distinctions between these persons can lead to a 'hierarchy' of assistance excluding those who do not fit 'neatly' into the definitions of refugee or trafficked person, but who still need help. In response, some prefer to use the term 'migrant' as a catch-all phrase for all persons who have crossed an international border. They argue that this usage not only better reflects the complex and interlinked drivers, root causes and experiences of human mobility and displacement today, but also avoids pitting refugees, migrants or trafficked persons against one another. ${ }^{1}$

Whilst accepting that assistance gaps for (irregular) migrants do exist, I contend that summarily referring to refugees or trafficked persons as 'migrants' is not the best solution. In making the argument for maintaining distinct legal categories, it

1 See, for example, J Carling, 'Refugee Advocacy and the Meaning of "Migrants", PRIO Policy Brief 2, Oslo, 2017, retrieved 2 January 2018, https://www.prio.org/ Publications $/$ Publication $/ \mathrm{P}_{\mathrm{x}}=10471$.

This is an open-access article distributed under the terms of the Creative Commons Attribution License (CC-BY). Under the CC-BY license, the public is free to share, adapt, and make commercial use of the work. Users must always give proper attribution to the authors and the Anti-Trafficking Review. 
is useful to begin by reflecting upon the reasons for such distinctions and upon the policies and practices that have evolved in response to, and in support of, their usage.

Nomenclature helps us sort through everyday language and ensures that, in some cases, legal consequences attach to words. At various points in history, a critical mass of states decided that the experience of particular individuals required an international response, distinguished them by a specific terminology and defined a detailed set of rules for their help and protection. The term 'refugee' exists because the international community recognised that some persons should not be returned to a place where their life or freedom is threatened. Unable to return home, refugees were granted a bundle of progressively accrued rights to enable them to rebuild their lives where they fled.

In law, a person is a refugee as soon as the elements in Article 1(a) of the 1951 Convention Relating to the Status of Refugees, interpreted alongside the 1967 Protocol Relating to the Status of Refugees, or the definitions found in regional refugee instruments, are met. Not identifying refugees as stipulated by these conventions, risks depriving them of the protections and freedoms that the international community decided to grant them. This is why, for over sixty years, the United Nations High Commissioner for Refugees has supported states to understand who refugees are, develop fair and efficient refugee status determination procedures, and adapt refugee protection tools to different contexts.

Developing an international definition of 'trafficking in persons' responded to another compelling global need. States sought to more effectively counter the burgeoning exploitation of people through deception or coercion, and to identify and support those affected. ${ }^{2}$ Since 2000, 173 states $^{3}$ have ratified or acceded to the Protocol to Prevent, Suppress and Punish Trafficking in Persons, Especially Women and Children ${ }^{4}$ and a majority have adopted anti-trafficking laws that generally reflect the internationally agreed definition. ${ }^{5}$ This definition, albeit imperfect, has also led

2 A Gallagher, The International Law of Human Trafficking, Cambridge University Press, Cambridge, 2010, p. 16.

3 UN Treaty Collection, retrieved 10 June 2018, https://treaties.un.org/Pages/ ViewDetails.aspx?src=IND\&mtdsg_no=XVIII-12-a\&chapter=18\&lang=en.

4 UN General Assembly, Protocol to Prevent, Suppress and Punish Trafficking in Persons, Especially Women and Children, Supplementing the United Nations Convention against Transnational Organized Crime, 15 November 2000.

5 Gallagher, p. 42. 
to the development of hundreds of international, regional and national protection mechanisms for trafficked persons.

These are clear reasons why legal categories should be maintained, and the distinctions between them respected.

While the term (irregular) migrant remains undefined in international law, migrants are people and, as such, do benefit from international human rights law regardless of their migration status. In cases where migrants are also workers, children, stateless persons, victims of torture or persons with disabilities, most states are obliged to provide additional support in accordance with specific international human rights instruments related to these categories. ${ }^{6}$ Unlike in the case of refugees, however, states are seldom required to allow (irregular) migrants to stay on their territories beyond the time required for the determination of their legal status. Moreover, no specific and internationally recognised community of practice exists to identify and provide assistance to (irregular) migrants in need of help, in contrast with the support networks available to both refugees and trafficked persons.

The real question, then, is how can clear and necessary distinctions between categories of people on the move be maintained, without a trade-off of rights to the disadvantage of (irregular) migrants? Currently, (irregular) migrants are too often deported to their home countries without sufficient consideration for other options that may be available to them; these deportations frequently involve the use of force or other violations of human rights. It is imperative, therefore, that the international community devise safe, fair and comprehensive systems for determining and implementing the proper treatment of irregular migrants, as a complement to, rather than in competition with, refugee status determination systems.

6 See, for example, the 1954 Convention Relating to the Status of Stateless Persons, the 1984 Convention Against Torture and other Cruel, Inbuman or Degrading Treatment or Punishment, the 1989 Convention on the Rights of the Child and the 1990 International Convention on the Protection of the Rights of All Migrant Workers and Members of Their Families. 
In addition to the forthcoming Global Compact for Refugees, and the Global Compact for Safe, Orderly and Regular Migration, international and regional entities have been working on new, globally applicable tools to guide states in how best to respond to the challenges of human cross-border mobility and displacement, in the spirit of international responsibility and cooperation. For example, the Office of the High Commissioner for Human Rights and the Global Migration Group recently published Principles and Guidelines on the Human Rights of Migrants in Vulnerable Situations, ${ }^{7}$ and the International Organization for Migration is developing a handbook that will support stakeholders in how to identify and assist vulnerable migrants in practice. Further, the Organization for Security and Cooperation in Europe is in the process of updating its seminal Handbook on National Referral Mechanisms (for victims of human trafficking), ${ }^{8}$ including a new chapter on immigration and asylum considerations.

However, only by ensuring that these initiatives provide more rather than less precision, and continue to respect existing legal categories designed to effectively meet the real needs of people on the move, can we forge ahead into a new paradigm of international agreement about how states should manage their borders, and respond to the needs of those crossing them.

Sarah Elliott is a legal officer at the UNHCR. She specialises in the fields of refugee law, migration studies and international criminal law, and the application of these frameworks to human trafficking and migrant smuggling. Her previous work at the UNHCR included implementing counter-trafficking programmes in partnership with the UNODC, UNICEF, UNFPA and IOM in Sudan. She was also instrumental in developing institutional policy guidance on counter-trafficking prevention and response initiatives within UNHCR's Asylum and Migration Unit, Division of International Protection. The views expressed here are the author's and do not represent the position of the UNHCR. Email: elliotts@unhcr.org.

7 Office of the High Commissioner for Human Rights and Global Migration Group, Principles and Guidelines, Supported by Practical Guidance, on the Human Rights Protection of Migrants in Vulnerable Situations, OHCHR/GMG, Geneva, 2018, retrieved 15 August 2018, https://www.ohchr.org/Documents/Issues/Migration/ PrinciplesAndGuidelines.pdf.

8 Organization for Security and Cooperation in Europe, National Referral MechanismsJoining Efforts to Protect the Rights of Trafficking Persons: A practical handbook, OSCE, Warsaw, 2004. 